\title{
Corrigendum to "Impact and Challenges of Mesenchymal Stem Cells in Medicine: An Overview of the Current Knowledge"
}

\author{
Farid Menaa $\mathbb{D}^{1},{ }^{1}$ Somayeh Shahrokhi $\mathbb{D},{ }^{2}$ and V. Prasad Shastri ${ }^{3}$ \\ ${ }^{1}$ Department of Oncology, Stem Cells, and Nanomedicine, California Innovations Corporation, La Jolla, San Diego, CA 92037, USA \\ ${ }^{2}$ Department of Immunology, Lorestan University of Medical Sciences, Khorramabad, Iran \\ ${ }^{3}$ Institute for Macromolecular Chemistry, Faculty of Chemistry and Pharmacy, BIOSS-Centre for Biological Signalling Studies, \\ University of Freiburg, Hermann Staudinger Haus, Stefan-Meier Strasse 31, Freiburg D-79104, Germany \\ Correspondence should be addressed to Farid Menaa; dr.fmenaa@gmail.com \\ Received 3 February 2019; Accepted 6 February 2019; Published 10 March 2019 \\ Copyright (C) 2019 Farid Menaa et al. This is an open access article distributed under the Creative Commons Attribution License, \\ which permits unrestricted use, distribution, and reproduction in any medium, provided the original work is properly cited.
}

In the article titled "Impact and Challenges of Mesenchymal Stem Cells in Medicine: An Overview of the Current Knowledge" [1], there was an error in the affiliation details of the last author, as the affiliation "Department of Cell Biology, University of Freiburg, Freiburg, Germany," was wrongly included.

The corrected authors' list and affiliations are shown above.

\section{References}

[1] F. Menaa, S. Shahrokhi, and V. Prasad Shastri, "Impact and challenges of mesenchymal stem cells in medicine: an overview of the current knowledge," Stem Cells International, vol. 2018, Article ID 5023925, 3 pages, 2018. 


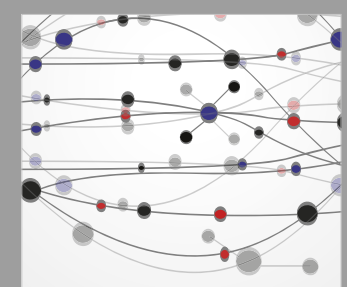

The Scientific World Journal
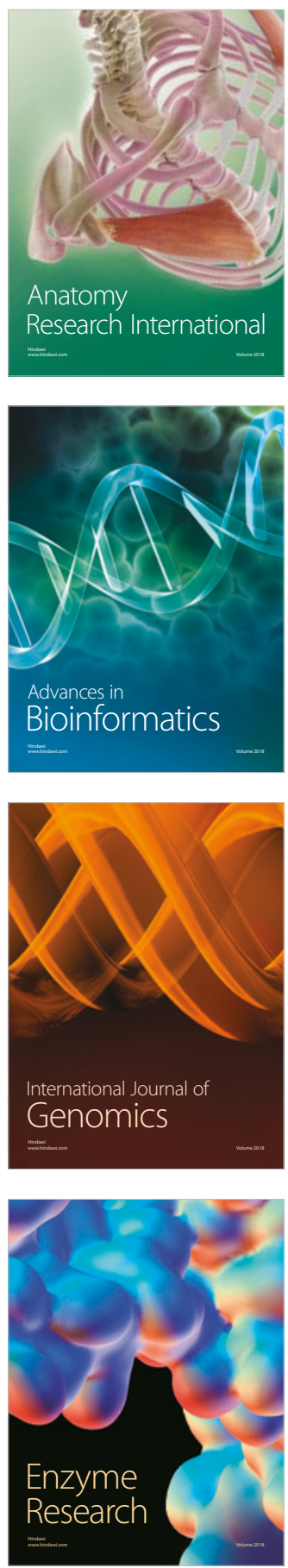
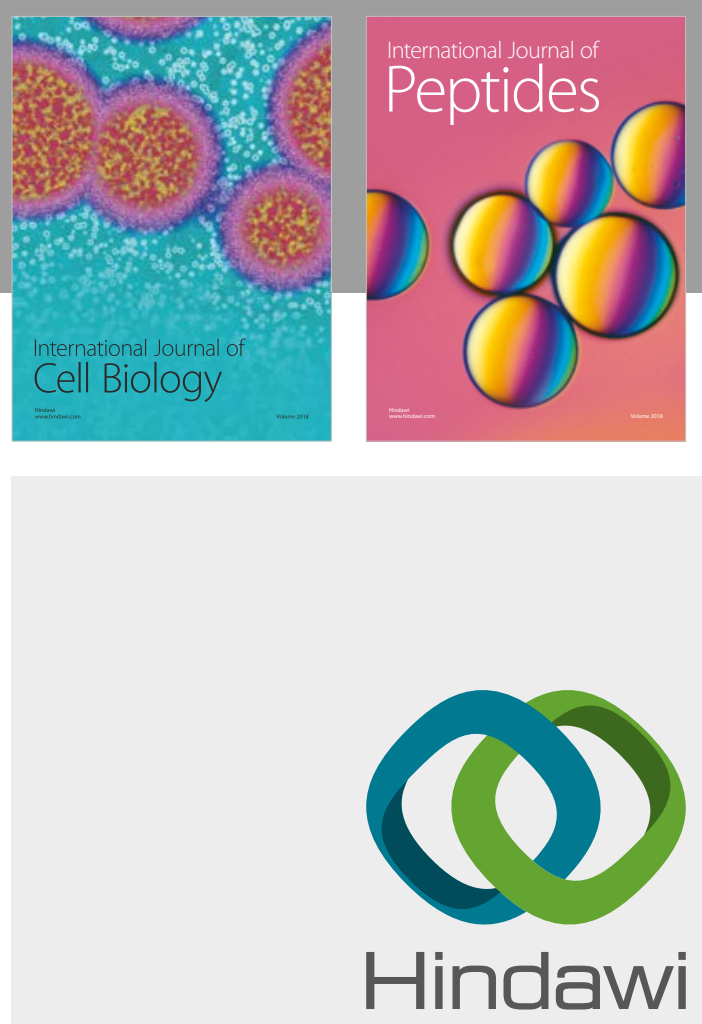

Submit your manuscripts at

www.hindawi.com
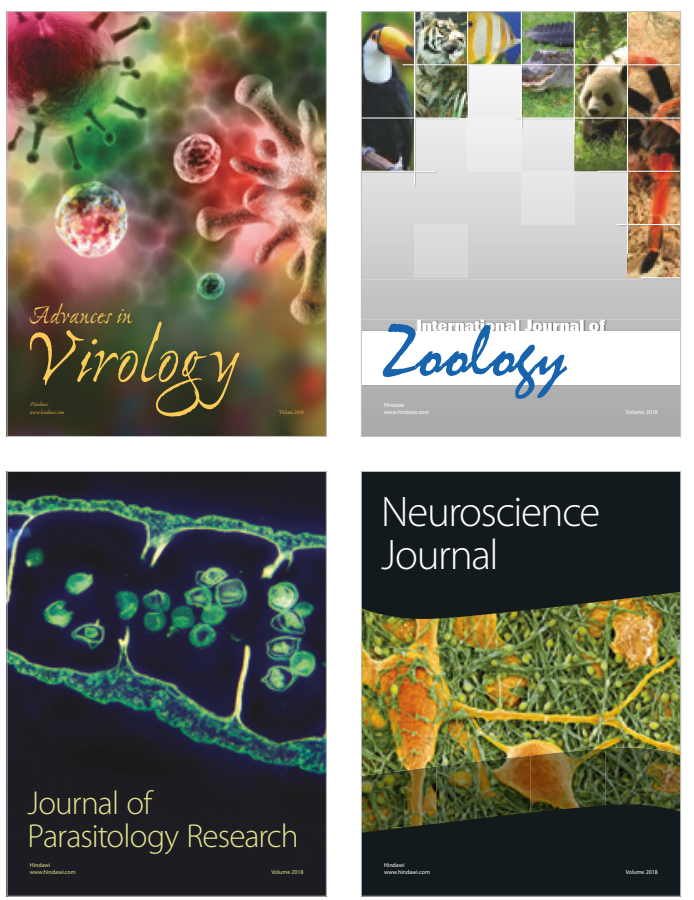
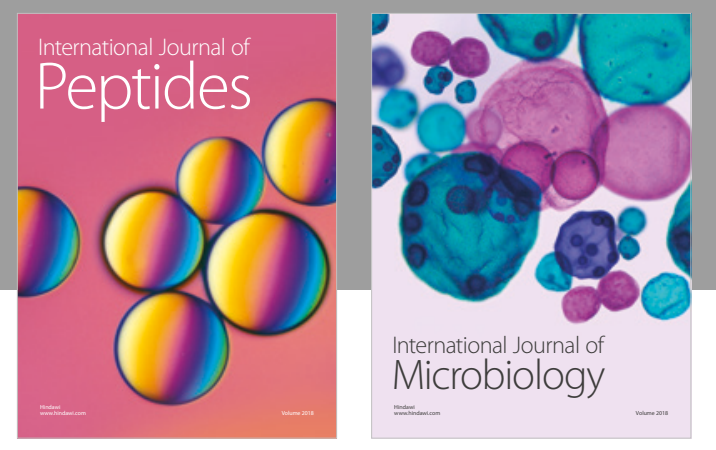

nternational Journal of Microbiology
Journal of
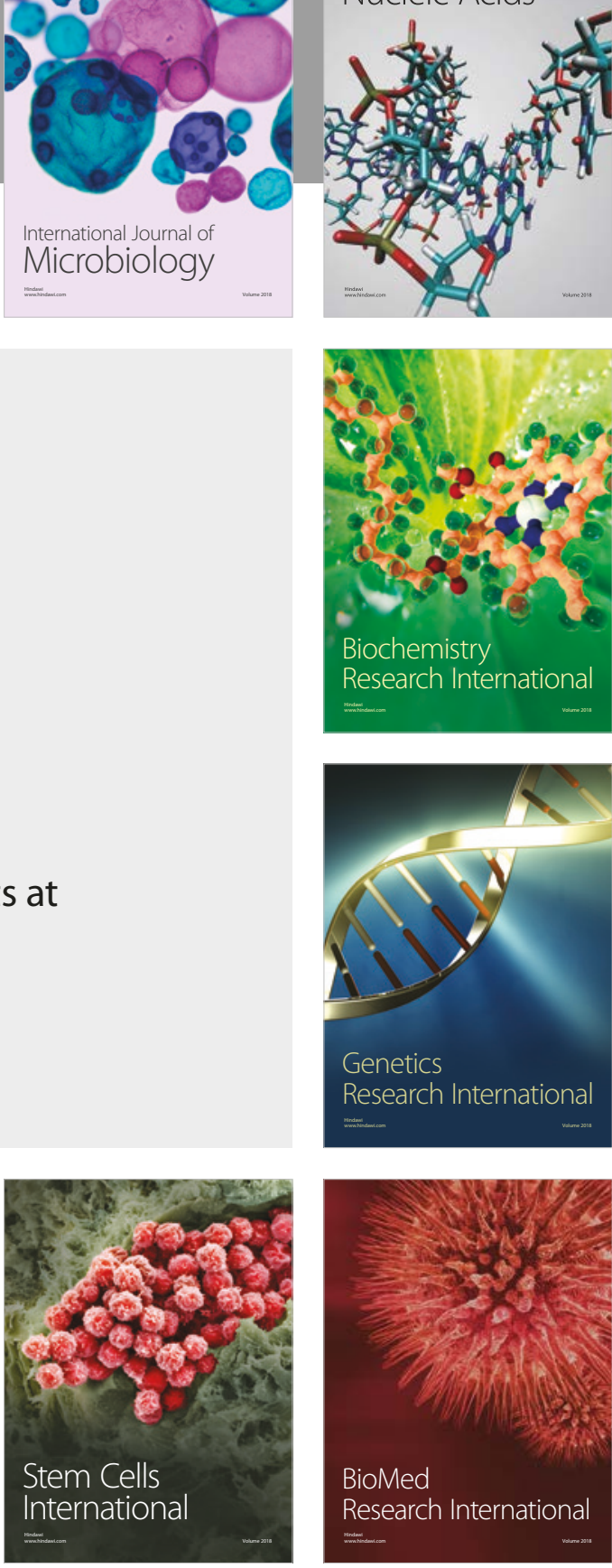
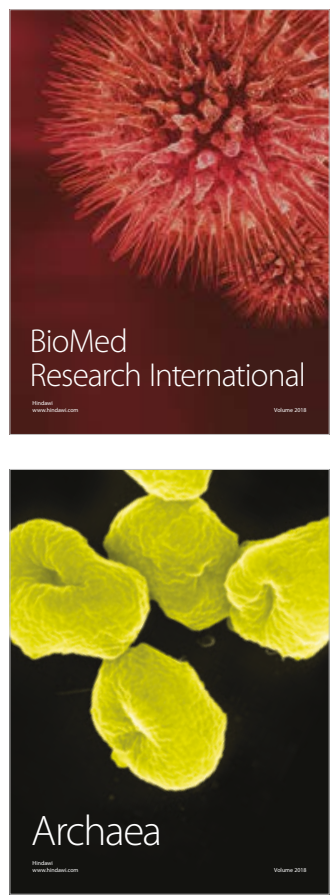